\title{
Relationship between Interest Rate and Stock Price: Empirical Evidence from Developed and Developing Countries
}

\author{
Md. Mahmudul Alam \\ Deputy Manager \\ CRM, Marketing Division, Grameenphone Ltd. \\ Dhaka, Bangladesh \\ E-mail: rony000@gmail.com \\ Md. Gazi Salah Uddin \\ Lecturer \\ School of Business, Presidency University \\ 11/A, Road-92, Gulshan-2 \\ Dhaka 1212, Bangladesh \\ E-mail: salahuddin@presidency.edu.bd
}

\section{Citation Reference:}

Alam, M.M., and Uddin, M.G.S. 2009. Relationship between Interest Rate and Stock Price: Empirical Evidence from Developed and Developing Countries, International Journal of Business and Management, Vol. 4(3), pp. 43-51. Available at <http://www.ccsenet.org/journal/index.php/ijbm/article/download/217/177>.

This is a pre-publication copy.

The published article is copyrighted by the publisher of the journal. 


\title{
Relationship between Interest Rate and Stock Price: Empirical Evidence from Developed and Developing Countries
}

\begin{abstract}
Stock exchange and interest rate are two crucial factors of economic growth of a country. The impacts of interest rate on stock exchange provide important implications for monitory policy, risk management practices, financial securities valuation and government policy towards financial markets. This study seeks evidence supporting the existence of share market efficiency based on the monthly data from January 1988 to March 2003 and also shows empirical relationship between stock index and interest rate for fifteen developed and developing countries- Australia, Bangladesh, Canada, Chile, Colombia, Germany, Italy, Jamaica, Japan, Malaysia, Mexico, Philippine, S. Africa, Spain, and Venezuela. Stationarity of market return is tested and found none of this stock market follows random walk model, means not efficient in weak form. To investigate the reasons of market inefficiency, relationship between share price and interest rate, and changes of share price and changes of interest rate were determined through both time series and panel regressions. For all of the countries it is found that interest rate has significant negative relationship with share price and for six countries it is found that changes of interest rate has significant negative relationship with changes of share price. So, if the interest rate is considerably controlled for these countries, it will be the great benefit of these countries' stock exchange through demand pull way of more investors in share market, and supply push way of more extensional investment of companies.
\end{abstract}

Keywords: Efficient Market Hypothesis, Random walk model, Market Return, Interest Rate, Investment, Panel study

\section{Introduction}

In prospects of overall economy, Ologunde, Elumilade, and Asaolu (2006) mentioned that share market makes it possible for the economy to ensure long-term commitments in real capital. For that reason, level of efficiency measurement of the stock market is very important to investors, policy makers and other major players, who ensure long-term real capital in an economy. A mature of the stock market efficiency level is perceived across the globe as a barometer of the economic health and prospect of a country as well as a register of the confidence of domestic and global investors.

Interest rate is one of the important macroeconomic variables, which is directly related to economic growth. Generally, interest rate is considered as the cost of capital, means the price paid for the use of money for a period of time. From the point of view of a borrower, interest rate is the cost of borrowing money (borrowing rate). From a lender's point of view, interest rate is the fee charged for lending money (lending rate).

Good investors always look for investing in an efficient market. In an inefficient market few people are able to generate extra ordinary profit causes of confidence losses of general people about the market. In such cases, if the rate of interest paid by banks to depositors increases, people switch their capital from share market to bank. This will lead to decrease the demand of share and to decrease the price of share and vice versa. On the other way, when rate of interest paid by banks to depositors increases, the lending interest rate also increases lead to decrease the investments in the economy which is also another reason of 
decreasing share price and vice versa. So, theoretically there is inverse relationship between share price and interest rate.

This paper examines the weak form efficiency of stock market for fifteen developed and developing countries, where the random walk theory is tested, that assumes consecutive price changes are independent and identically distributed over time so that past values of the index cannot be used to forecast the current values. To investigate the reasons of market inefficiency, this paper further investigates the dimension of relationship between Share Price and Interest Rate, and Changes of Share Price with Changes of Interest Rate.

\section{Review of Empirical Evidence}

The findings from the empirical testing of the efficient market hypothesis (i.e., random walk) with stock prices have been mixed. Early studies by Fama (1965), Samuelson (1965), and Working (1960) could not reject a random walk. Shiller (1989) indicated that there are reasons that the random-walk behaviour of stock prices should hold, and there is plenty of evidence suggesting that stock prices do follow a random walk. An early rejection of a random walk was found by Niederhoffer \& Osborne (1966). Poterba \& Summers (1988) argued that there is little theoretical basis for strong attachment to the null hypothesis that stock prices follow a random walk. Lo \& MacKinlay (1988) investigated the sampling distributions of variance ratios over different sampling intervals and found that stock returns do not follow a random walk. Claessens (1995) in a world bank study reported significant serial correlation in equity returns from 19 emerging markets and suggested that stock prices in emerging markets violates weak form EMH. Poshakwale (1996) found the evidence of non-randomness stock price behavior and the market inefficiency (not weak-form efficient) on the Indian market. Khababa (1998) has examined the behavior of stock price in the Saudi Financial market seeking evidence that for weak-form efficiency and found that the market was not weak-form efficient. $\mathrm{He}$ explained that the inefficiency might be due to delay in operations and high transaction cost, thinness of trading and illiquidity in the market.

While working on Johannesburg Stock Exchange (JSE), Jammine and Hawkins (1974), Hadassin (1976) and Du Toit (1986) reject week-form efficiency, but Affleck-Graves and Money (1975), Gilbertson and Roux (1977, 1978) found week-form efficiency; Knight and Afflect-Graves (1983) rejected semi-strong form efficiency but Knight, AfflectGraves and Hamman (1985) showed semi-strong form efficiency; Gilbertson (1976) found evidence supporting strong-form efficiency, but Knight and Firer (1989) rejected the strong-form efficiency. Given the mixed evidence on efficiency of JSE, Thompson and Ward (1995) showed that there are some share price dependencies but too small to profitably exploited and concluded that JSE is "operationally efficient" that means only a small group of investors are able to outperform the market.

Although some studies (Balaban 1995, Urrutia 1995, Grieb \& Reyes 1999, Kawakatsu \& Morey 1999) support non randomness of emerging markets' stock prices, some other studies related to these same markets (Butler \& Malaikah, 1992, and Panas, 1990) do not. Harvey (1993) stated that stock returns of emerging countries are highly predictable and have low correlation with stock returns of developed countries. He concluded that emerging markets are less efficient than developed markets and that higher return and low risk can be obtained by incorporating emerging market stocks in investors' portfolios. 
The relationship between stock prices and interest rates has received considerable attention in the literature. Fama (1981) argues that expected inflation is negatively correlated with anticipated real activity, which in turn is positively related to returns on the stock market. Therefore, stock market returns should be negatively correlated with expected inflation, which is often proxied by the short-term interest rate. On the other hand, the influence of the long-term interest rate on stock prices stems directly from the present value model through the influence of the long-term interest rate on the discount rate. Rather than using either short-term or long-term interest rates, Campbell (1987) analyzed the relationship between the yield spread and stock market returns. He argues that the same variables that have been used to predict excess returns in the term structure also predicts excess stock returns, deducing that a simultaneous analysis of the returns on bills, bonds and stock should be beneficial. His results support the effectiveness of the term structure of interest rates in predicting excess returns on the US stock market. Kaul (1990) studied the relationship between expected inflation and the stock market, which, according to the proxy hypothesis of Fama (1981) should be negatively related since expected inflation is negatively correlated with anticipated real activity, which in turn is positively related to returns on the stock market. Instead of using the short-term interest rate as a proxy for expected inflation, Kaul (1990) explicitly models the relationship between expected inflation and stock market returns. Zhou (1996) also studied the relationship between interest rates and stock prices using regression analysis. He found that interest rates have an important impact on stock returns, especially on long horizons, but the hypothesis that expected stock returns move one-for-one with ex ante interest rates is rejected. In addition, his results show that long-term interest rate explain a major part of the variation in pricedividend ratios and suggests that the high volatility of the stock market is related to the high volatility of long-term bond yields and may be accounted for by changing forecasts of discount rates.

Lee (1997) used three-year rolling regressions to analyze the relationship between the stock market and the short-term interest rate. He tried to forecast excess returns (i.e. the differential between stock market returns and the risk-free short-run interest rate) on the Standard and Poor 500 index with the short-term interest rate, but found that the relationship is not stable over time. It gradually changes from a significantly negative to no relationship, or even a positive although insignificant relationship. Jefferis and Okeahalam (2000) worked on South Africa, Botswana and Zimbabwe stock market, where higher interest rates are hypothesized to depress stock prices through the substitution effect (interest-bearing assets become more attractive relative to shares), an increase in the discount rate (and hence a reduced present value of future expected returns), or a depressing effect on investment and hence on expected future profits. Harasty and Roulet (2000) worked on 17 developed countries and showed that stock prices are cointegrated with earnings (a proxy for dividends) and the longterm interest rate in each country (except the Italian market for which the short-term interest rate was used). Spyrou (2001) also studied the relationship between inflation and stock returns but for the emerging economy of Greece. Consistent with Kaul's results, Spyrou (2001) found that inflation and stock returns are negatively related, but only up to 1995 after which the relationship became insignificant.

Arango (2002) found that some evidence of the nonlinear and inverse relationship between the share prices on the Bogota stock market and the interest rate as measured by the inter bank loan interest rate, which is to some extent affected by monetary policy. The model captures the stylized fact on this market of high dependence of returns in short periods. 
These findings do not support any efficiency on the main stock market in Colombia. Hsing (2004) adopts a structural VAR model that allows for the simultaneous determination of several endogenous variables such as, output, real interest rate, exchange rate, the stock market index and found that there is an inverse relationship between stock prices and interest rate. Zordan (2005) said that historical evidence illustrates that stock prices and interest rates are inversely correlated, with cycle's observable well back into the 1880's; more relevant to the period subsequent to World War II. From the late 1940's to the mid 1960's, inflation was low, and interest rates were both low and stable. Stocks did well during this period, both in nominal and real terms. The inverse relationship between interest-sensitive asset classes like stocks, bonds, and real estate and commodity prices has been known through history. That relationship can be observed in the 1877 to 1906 cycle, the 1906 to 1920 cycle, the 1920 to 1929 cycle, the 1929 to 1949 cycle, and the 1949 to 1966 cycle. Uddin and Alam (2007) examines the linear relationship between share price and interest rate, share price and changes of interest rate, changes of share price and interest rate, and changes of share price and changes of interest rate on Dhaka Stock Exchange (DSE). For all of the cases, included and excluded outlier, it was found that Interest Rate has significant negative relationship with Share Price and Changes of Interest Rate has significant negative relationship with Changes of Share Price.

As different study shows mixed results, this study will test the random walk model and check the effects of Share Price on Interest Rate and Changes of Share Prices on Changes of Interest Rate, both in time series and panel approach, for fifteen developed and developing countries.

\section{Data, Model and Methodology}

The sample includes fifteen countries' monthly observations from January 1988 to March 2003. The data - "Schedule Banks Fixed (3-6) Mos." and "Stock Exchange Index"- is taken from International Financial Statistics (IFS). As representative of interest rate data, Bank Deposit Rate is used because deposit rate usually refers to rates offered to resident customers for demand time or savings deposits. Also as representative of share price, share market index is considered because it is considered as less risky return from market. Based on economic condition, geographic locations and data availability in IFS, fifteen countries were selected. Out of fifteen countries, seven are developed countries (Australia, Canada, Germany, Italy, Japan, South Africa, Spain) and eight are developing countries (Bangladesh, Chile, Colombia, Jamaica, Malaysia, Mexico, Philippine, Venezuela). Selected countries are also geographically well distributed, where four from Asia (Bangladesh, Japan, Malaysia, Philippine), three from Europe (Italy, Germany, Spain), three from North America (Jamaica, Canada, Mexico), three from South America (Chile, Colombia, Venezuela), one from Africa (South Africa), and another one is Australia.

To test the randomness of market, the tools of stationarity of share prices is tested by using market returns. Market returns $\left(\mathrm{R}_{\mathrm{t}}\right)$ are calculated from the monthly price indices such as follows:

$$
\mathrm{R}_{\mathrm{t}}=\operatorname{Ln}\left(\mathrm{PI}_{\mathrm{t}} / \mathrm{PI}_{\mathrm{t}-1}\right)
$$

Where, $\mathrm{R}_{\mathrm{t}}=$ market return at period $\mathrm{t} ; \mathrm{PI}_{\mathrm{t}}=$ price index at period $\mathrm{t} ; \mathrm{PI}_{\mathrm{t}-1}=$ the price index at period $\mathrm{t}-1 ; \ln =$ natural $\log$ 
Here the linear relationship between the dependent and the independent variables was determined through panel approach for the regression analysis and inferences were drawn based on the regression analysis.

$$
\mathrm{Y}_{1 \mathrm{it}}=\beta_{0 \mathrm{i}}+\beta_{1 \mathrm{i}} \mathrm{X}_{1 \mathrm{it}}+\mathrm{u}_{\mathrm{lt}}
$$

In equation-2, it is regress Share price $\left(\mathrm{Y}_{1}\right)$ on Interest Rate $\left(\mathrm{X}_{1}\right)$ to look at how prevailing Interest Rate influences the Price of Stock Market.

$$
\mathrm{Y}_{2 \mathrm{it}}=\beta_{0 \mathrm{i}}+\beta_{1 \mathrm{i}} \mathrm{X}_{2 \mathrm{it}}+\mathrm{u}_{\mathrm{it}}
$$

In equation-3, it is regressed Changes of Share Price $\left(\mathrm{Y}_{2}\right)$ on Changes of Interest Rate $\left(\mathrm{X}_{2}\right)$ to look at how prevailing Changes of Interest Rate influences the Changes of Price of Stock Market. Changes of Share Price and Changes of Interest Rate are calculated from monthly Share Price and monthly Interest Rate such as follows:

$$
\begin{aligned}
& \mathrm{Y}_{2}=100 *\left[\mathrm{Y}_{1(\mathrm{t})}-\mathrm{Y}_{1(\mathrm{t}-1)}\right] / \mathrm{Y}_{1(\mathrm{t}-1)} \\
& \mathrm{X}_{2}=100 *\left[\mathrm{X}_{1(\mathrm{t})}-\mathrm{X}_{1(\mathrm{t}-1)}\right] / \mathrm{X}_{1(\mathrm{t}-1)}
\end{aligned}
$$

Where, $\mathrm{Y}_{2}=$ changes of share price at period $\mathrm{t} ; \mathrm{Y}_{1(\mathrm{t})}=$ share price at period $\mathrm{t} ; \mathrm{Y}_{1(\mathrm{t}-1)}=$ share price at period $\mathrm{t}-1 ; \mathrm{X}_{2}=$ changes of interest rate at period $\mathrm{t} ; \mathrm{X}_{1(\mathrm{t})}=$ interest rate at period $\mathrm{t} ; \mathrm{X}_{1(\mathrm{t})}=$ interest rate at period $\mathrm{t}-1$.

\section{Empirical Result and Analysis}

\subsection{Market Efficiency Test}

The statistical output of unit root test for individual market suggests that there are serial dependencies of return of all Stock Exchanges. ADF calculated values are significant at 99\% confidence level for all 10 degrees of freedom (lags) for all 15 countries suggest that none of these market follows random walk model (Table-1: Eq-1), means none of these market is efficient in week form.

$$
<<\text { Table 1 >> }
$$

\subsection{Panel Data Analysis on Interest Rate \& Share Price}

The probability of $F$ test for no fixed effects cannot be accepted at 0.000 significant levels both for one way and two way fixed effects model, that means there are fixed effects. At a very low (0.0001) significance level (Table-2: Eq-2), it is found that Interest Rate $\left(\mathrm{X}_{1}\right)$ has significant relationship on Share price $\left(\mathrm{Y}_{1}\right)$ and the coefficient of independent variable, 2.08 for one way fixed effect and -0.95 for two way fixed effects, shows there is a negative relationship between the two variables. The coefficient of determination $\left(\mathrm{R}^{2}\right)$ indicates that $37 \%$ of the total variation in the dependent variable is account for by the independent variable by one way fixed effect, while $56 \%$ of the total variation in the dependent variable is account for by the independent variable by two way fixed effects. 
The probability of m-test cannot be accepted at $98 \%$ confidence levels for one way and at 0.000 significance level for two way random effects model, which means fixed effects is more appropriate than random effect. But for reporting it is mentioned that at a very low (0.0001) significance level (Table-3: Eq-2), it is found that Interest Rate $\left(\mathrm{X}_{1}\right)$ has significant relationship on Share price $\left(\mathrm{Y}_{1}\right)$ and the coefficient of independent variable, 2.06 for one way random effect and -1.18 for two way random effects, shows there is a negative relationship between the two variables.

$<<$ Table 3>>

\subsection{Panel Data Analysis on Changes of Interest Rate \& Changes of Share Price}

The probability of $\mathrm{F}$ test for no fixed effects cannot be accepted at $97 \%$ confidence interval for one way and at 0.00 significance level for two way fixed effects model, that means there are fixed effects. At a very low (0.006) significance level (Table-4: Eq-3), it is found that Changes of Interest Rate $\left(\mathrm{X}_{2}\right)$ has significant relationship on Changes of Share Price $\left(\mathrm{Y}_{2}\right)$ and the coefficient of independent variable, -0.03 for one way fixed effect and 0.02 for two way fixed effects at (0.06) significance level, shows there is a negative relationship between the two variables. The coefficient of determination $\left(\mathrm{R}^{2}\right)$ indicates that only $1 \%$ of the total variation in the dependent variable is account for by the independent variable by one way fixed effect while $15 \%$ of the total variation in the dependent variable is account for by the independent variable by two way fixed effects.

$$
<<\text { Table 4>> }
$$

The probability of m-test cannot be rejected at (0.41) significance levels for one way and cannot be accepted at (0.068) significance level for two way random effects model, that means one way random effect is better than fixed effect and fixed effect is better than two way random effects. At a very low (0.007) significance level (Table-5: Eq-3), it is found that Changes of Interest Rate $\left(\mathrm{X}_{2}\right)$ has significant relationship on Changes of Share Price $\left(\mathrm{Y}_{2}\right)$ and the coefficient of independent variable is -0.03 for one way random effect and at a very low (0.002) significance level two way random effects shows a negative relationship (coefficient is -0.03 ) between the two variables.

$$
<<\text { Table 5>> }
$$

\subsection{Country-wise Time Series Analysis on Interest Rate and Share Price}

Individual country wise OLS (Table-6: Eq-2) shows (except Malaysia and Philippine) 13 countries data are significant at a very low (0.0001) significance level that Interest Rate $\left(\mathrm{X}_{1}\right)$ has significant relationship on Share price $\left(\mathrm{Y}_{1}\right)$, where except Japan other 12 countries' coefficient of independent variable shows there is a negative relationship between two variables.

$<<$ Table 6>>

\subsection{Country-wise Time Series Analysis on Changes of Interest Rate and Changes of Share Price}

Individual country wise OLS (Table-7: Eq-3) shows 6 countries' - Bangladesh, Colombia, Italy, Japan, Malaysia, S. Africa- data are significant at 95\% confidence interval where 
change of Interest Rate $\left(\mathrm{X}_{2}\right)$ has significant relationship on change of Share Price $\left(\mathrm{Y}_{2}\right)$ and the coefficient of independent variable shows there is a negative relationship between two variables.

$$
<<\text { Table 7>> }
$$

\section{Conclusion}

This study examines the market efficiency of fifteen countries and also looks about the effect of interest rate on share price and changes of interest rate on changes of share price. The randomness of stock return is the basic assumption of Efficient Market Hypothesis that is violated for all countries' Stock Exchange, means these markets are not efficient in weak form. In overall, the theoretical argument of negative relationship between stock price and prevailing interest rate is not rejected. Individual country result is mixed for both developed and developing countries. Interestingly, for Malaysia it is found that Interest Rate has no relation with Share price but Changes of Interest Rate has negative relationship with Changes of Share Price. In case of Japan, it is found that Interest Rate has positive relationship with Share price but change of Interest Rate has negative relationship with change of Share Price. Four countries like Bangladesh, Colombia, Italy, and S. Africa shows negative relationship for both Interest Rates with Share price and Changes of Interest Rate with Changes of Share Price. Eight countries like, Australia, Canada, Chile, Germany, Jamaica, Mexico, Spain, and Venezuela has significant negative relationship between Interest Rates and Share price but no relationship between change of Interest Rate and change of Share Price. So, except Philippine all other countries show significant negative relationship either Interest Rates with Share price or Changes of Interest Rate with Changes of Share Price or both. So, if the interest rate is considerably controlled in these countries, it will be the great benefit for their Stock Exchange through demand pull way of more investor in share market, and supply push way of more extensional investment of companies.

\section{References}

Affleck-Graves, J. F. and Money, A. H. (1975). A Note on the Random Walk Model and South African Share Prices. The South African Journal of Economics, 43(3), 382-388.

Arango, L. E., Gonzalez, A. and Posada, C. E. (2002). Returns and interest rate: A nonlinear relationship in the Bogotá stock market. Applied Financial Economics, 12(11), 835-842.

Balaban, E. (1995). Day of the Week Effects: New Evidence from an Emerging Stock Market. Applied Economics Letters, 2(5), 139-143.

Butler, K.C. and Mailaikah, S. J. (1992). Efficiency and Inefficiency in Thinly Traded Stock Markets: Kuwait and Saudi Arabia. Journal of Banking and Finance, 16, 197-210.

Campbell, J.Y. (1987). Stock Returns and the Term Structure. Journal of Financial Economics, 18, 373-399.

Claessens, S., Dasgupta, S. and Glen, J. (1995). Return Behaviour in Emerging Stock Markets. The World Bank Economic Review, 9(1), 131-151.

Du Toit, G. S. (1986). Technical Analysis and Market Efficiency on the Johannesburg Stock Exchange. Working Paper for D.Com degree, Pretoria: University of Pretoria.

Fama, E. (1965). The Behavior of Stock Market Prices. Journal of Business, 38, 34-105. (1981). Stock returns, real activity, inflation and money. American Economic Review, 71, 545-564. 
Gilbertson, B. P. (1976). The Performance of South African Mutual Funds. Report No. F76/84, Johannesburg: Johannesburg Consolidated Investment Company.

Grieb, T. A. and Reyes, M. G. (1999). Random Walk Tests for Latin American Equity Indexes and Individual Firms. Journal of Financial Research, 22(4), 371-383.

Hadassin, I. (1976). An Investigation into the Bahavior of Emerging and Share Prices of South African Listed Companies. Investment Analysts Journal, 8, 13-24.

Harasty, H. and Roulet, J. (2000). Modeling Stock Market Returns. Journal of Portfolio Management, 26 (2), 33.

Harvey, A. C. (1993). Time Series Models. 2nd Edition, New York: Harvester Wheatsheaf.

Hsing, Y. (2004). Impacts of Fiscal Policy, Monetary Policy, and Exchange Rate Policy on Real GDP in Brazil: A VAR Model. Brazilian Electronic Journal of Economics, 6 (1).

Jammine, A.P. and Hawkins, D.M. (1974). The Behavior of Some Share Indices: A Statistical Analysis. The South African Journal of Economics, 42(1), 43-55.

Jefferis, K. R. and Okeahalam, C. C. (2000). The Impact of Economic Fundamentals on Stock Markets in Southern Africa. Development Southern Africa, 17(1), 23-51.

Kaul, G. (1990). Monetary Regimes and the relation between stock returns and inflationary expectations. Journal of Financial and Quantitative Analysis, 15, 307321.

Kawakatsu, H. and Morey, M. R. (1999). An Empirical Examination of Financial Liberalization and the Efficiency of Emerging Market Stock Prices. The Journal of Financial Research, 22, 385-411.

Khababa, N. (1998). Behavior of stock prices in the Saudi Arabian Financial Market: Empirical research findings. Journal of Financial Management \& Analysis, 11(1), 48-55.

Knight, E. T. and Firer, C. (1989). The Performance of South African Unit Trusts 1977-1986. The South African Journal of Economics, 57(1), 52-68.

Knight, R. F. and Affleck-Graves, J. F. (1983). The Efficient Market Hypothesis and a Change to LIFO: An Empirical Study on the JSE. Investment Analysts Journal, 21, 21-33.

Knight, R. F., Affleck-Graves, J. F. and Hamman, W. D. (1985). The Effect of Inventory Valuation Methods on Share Prices: Some New Evidence for the JSE. Investment Analysts Journal, 26, 45-47.

Lee, W. (1997). Market timing and short-term interest rates. Journal of Portfolio Management, 23 (3), 35-46.

Lo, A.W. and Mackinlay, A.C. (1988). Stock Market Prices Do Not Follow Random Walks: Evidence from A Simple Specification Test. Review of Financial Studies, 1, 41-66.

Niederhoffer, V. and Osborne, M.F.M. (1966). Market Making and Reversal on the Stock Exchange. Journal of the American Statistical Association, 61, 897-916.

Ologunde, A.O., Elumilade, D.O. and Asaolu, T. O. (2006). Stock Market Capitalization and Interest Rate in Nigeria: A Time Series Analysis. International Research Journal of Finance and Economics, 4, 154-166.

Panas, E. E. (1990). The Behaviour of Athens Stock Prices. Applied Economics, 22(12), 1915-1727.

Poshakwale, S. (1996). Evidence on the Weak-form efficiency and the day of the week effect in the Indian Stock Market. Finance India, 10(3), 605-616.

Poterba, J. M. and Summers, L. H. (1988). Mean Reversion in Stock Returns: Evidence and Implications. Journal of Financial Economics, 22, 27-59. 
Roux, F. J. P. and Gilbertson, D. P. (1978). The behavior of share prices on the Johannesburg Stock Exchange. Journal of Business Finance and Accounting, 5(2), 223-232.

Samuelson, P. A. (1965). Proof that Properly Anticipated Prices Fluctuate Randomly. Industrial Management Review, 6, 41-49.

Shiller, R. J. (1989), Market Volatility, Massachusetts: M.I.T. Press.

Spyrou, I. S. (2001). Stock returns and inflation: evidence from an emerging market. Applied Economics Letters, 8, 447-450.

Strong, N. (1992). Modelling Abnormal Returns: A Review Article. Journal of Business Finance and Accounting, 19(4), 533-553.

Thompson, A. R. and Ward, M. J. D. (1995). The Johannesburg Stock Exchange as an Efficient Market: A Review. Journal of Studies in Economics and Econometrics, 19(3), 33-63.

Uddin, M. G. S. and Alam, M. M. (2007). The Impacts of Interest Rate on Stock Market: Empirical Evidence from Dhaka Stock Exchange. South Asian Journal of Management and Sciences, 1(2), 123-132.

Urrutia, J. L. (1995). Tests of Random Walk and Market Efficiency for Latin American Emerging Markets. Journal of Financial Research, 18, 299-309.

Zhou, C. (1996). Stock Market Fluctuations and the Term Structure. Board of Governors of the Federal Reserve System, Finance and Economics Discussion Series: 96/03.

Zordan, D. J. (2005). Stock Prices, Interest Rates, Investment Survival. Econometrica USA, Illinois. [Online] Available: http://www.econometricausa.com/publications/StockPrices.pdf 
Table No. 1: Unit Root Test: t-Value of ADF for Share Price [for 10 leg period] (Eq-1)

\begin{tabular}{|c|c|c|c|c|c|c|c|c|c|c|}
\hline Lag Period & 1 & 2 & 3 & 4 & 5 & 6 & 7 & 8 & 9 & 10 \\
\hline Australia & $-9.29 *$ & $-7.67 *$ & $-6.98 *$ & $-6.54 *$ & $-6.00 *$ & $-4.85^{*}$ & $-4.64 *$ & $-4.33 *$ & $-3.94 *$ & $-4.22 *$ \\
\hline Bangladesh & $-8.62 *$ & $-6.70 *$ & $-6.03 *$ & $-6.32 *$ & $-6.16^{*}$ & $-4.66^{*}$ & $-4.41 *$ & $-4.48 *$ & $-4.35^{*}$ & $-4.29 *$ \\
\hline Canada & $-8.85^{*}$ & $-7.13^{*}$ & $-6.97 *$ & $-6.32 *$ & $-5.25 *$ & $-4.46^{*}$ & $-4.31 *$ & $-3.87 *$ & $-3.40 *$ & $-3.38 *$ \\
\hline Chile & $-8.45^{*}$ & $-6.27^{*}$ & $-6.67 *$ & $-5.44 *$ & $-5.01 *$ & $-4.18^{*}$ & $-3.89 *$ & $-3.65 *$ & $-3.25^{*}$ & $-3.14 *$ \\
\hline Colombia & $-7.79 *$ & $-7.06^{*}$ & $-5.83 *$ & $-4.82 *$ & $-4.13 *$ & $-3.93 *$ & $-3.92 *$ & $-3.84 *$ & $-3.63 *$ & $-3.40 *$ \\
\hline Germany & $-8.37 *$ & $-6.77 *$ & $-5.55^{*}$ & $-5.15^{*}$ & $-4.62 *$ & $-4.32 *$ & $-3.98 *$ & $-3.78 *$ & -2.61 & -2.15 \\
\hline Italy & $-8.20 *$ & $-6.29 *$ & $-6.08 *$ & $-5.79 *$ & $-5.50 *$ & $-5.33^{*}$ & $-4.18 *$ & $-3.14 *$ & $-3.08 *$ & -2.62 \\
\hline Jamaica & $-7.63 *$ & $-6.07 *$ & $-5.57 *$ & $-4.96 *$ & $-4.56^{*}$ & $-5.13^{*}$ & $-4.80 *$ & $-4.88 *$ & $-4.63 *$ & $-4.11 *$ \\
\hline Japan & $-8.28 *$ & $-7.30 *$ & $-5.79 *$ & $-5.46^{*}$ & $-5.41 *$ & $-4.53^{*}$ & $-4.53 *$ & $-4.05 *$ & $-3.69 *$ & $-3.44 *$ \\
\hline Malaysia & $-7.96 *$ & $-7.66^{*}$ & $-6.68 *$ & $-6.12 *$ & $-5.63 *$ & $-4.18 *$ & $-3.88 *$ & $-3.38 *$ & $-3.40 *$ & $-3.62 *$ \\
\hline Mexico & $-9.05^{*}$ & $-7.30 *$ & $-6.84 *$ & $-5.94 *$ & $-6.16^{*}$ & $-5.18^{*}$ & $-4.73 *$ & $-4.16^{*}$ & $-3.23 *$ & $-3.35^{*}$ \\
\hline Philippine & $-11.09 *$ & $-9.18 *$ & $-7.60 *$ & $-6.20 *$ & $-5.88 *$ & $-4.77 *$ & $-4.60 *$ & $-4.30 *$ & $-4.33 *$ & $-4.48 *$ \\
\hline S. Africa & $-9.01 *$ & $-7.03^{*}$ & $-7.38 *$ & $-6.48^{*}$ & $-5.89 *$ & $-5.71 *$ & $-4.92 *$ & $-4.76^{*}$ & $-4.69 *$ & $-3.86^{*}$ \\
\hline Spain & $-9.29 *$ & $-6.98 *$ & $-6.33^{*}$ & $-6.36^{*}$ & $-5.54 *$ & $-4.99 *$ & $-4.59 *$ & $-3.80 *$ & $-3.11 *$ & -2.81 \\
\hline Venezuela & $-9.31 *$ & $-7.50 *$ & $-6.19 *$ & $-5.48 *$ & $-4.91 *$ & $-4.58 *$ & $-4.19 *$ & $-3.95 *$ & $-3.98 *$ & $-4.08 *$ \\
\hline
\end{tabular}

* Significant at $99 \%$ confidence level

\begin{tabular}{ccrccccc}
\hline \multicolumn{7}{c}{ Table No. 02: Stock Prices Regressed on Interest Rate (Eq-2) } \\
\hline \multirow{2}{*}{ Method } & Model & Coefficient & $\begin{array}{c}\text { t- } \\
\text { Value }\end{array}$ & $\begin{array}{c}\mathrm{p}- \\
\text { Value }\end{array}$ & $\mathrm{R}^{2}$ & F-Value & F-Prob. \\
\hline \hline $\begin{array}{c}\text { One-way } \\
\text { Fixed } \\
\text { Effect }\end{array}$ & Constant & 110.86 & 32.7 & 0.0001 & & & \\
\hline $\begin{array}{c}\text { Two-way } \\
\text { Fixed }\end{array}$ & Constant & -2.08 & -23.97 & 0.0001 & 0.37 & 88.94 & 0.0000 \\
Effect & Interest Rate & -0.93 .83 & 11.94 & 0.0001 & & & \\
\hline \hline
\end{tabular}

Table No. 03: Stock Prices Regressed on Interest Rate (Eq-2)

\begin{tabular}{ccrrrrrr}
\hline Method & Model & Coefficient & Value & $\mathrm{p}$-Value & $\mathrm{R}^{2}$ & $\mathrm{~m}$-Value & m-Prob. \\
\hline \hline $\begin{array}{c}\text { One-way } \\
\text { Random } \\
\text { Effect }\end{array}$ & Constant & 95.09 & 15.53 & 0.0001 & & & \\
\hline $\begin{array}{c}\text { Two-way } \\
\text { Random } \\
\text { Effect }\end{array}$ & Constant & -2.06 & -23.85 & 0.0001 & 0.17 & 5.64 & 0.0180 \\
\hline \hline
\end{tabular}

\begin{tabular}{|c|c|c|c|c|c|c|c|}
\hline \multicolumn{8}{|c|}{ Table No. 04: Changes of Stock Prices Regressed on Changes of Interest Rate (Eq-3) } \\
\hline Method & Model & Coefficient & $\begin{array}{c}\mathrm{t}- \\
\text { Value }\end{array}$ & $\begin{array}{c}\mathrm{p}- \\
\text { Value }\end{array}$ & $\mathrm{R}^{2}$ & F-Value & F-Prob. \\
\hline One-way & Constant & 2.52 & 3.88 & 0.0001 & \multirow[b]{2}{*}{0.01} & \multirow[b]{2}{*}{1.86} & \multirow[b]{2}{*}{0.026} \\
\hline $\begin{array}{l}\text { Fixed } \\
\text { Effect }\end{array}$ & Interest Rate & -0.03 & -2.76 & 0.0057 & & & \\
\hline Two-way & Constant & 0.46 & 0.20 & 0.8390 & \multirow[b]{2}{*}{0.15} & \multirow[b]{2}{*}{2.26} & \multirow[b]{2}{*}{0.000} \\
\hline $\begin{array}{l}\text { Fixed } \\
\text { Effect }\end{array}$ & Interest Rate & -0.02 & -1.86 & 0.0633 & & & \\
\hline
\end{tabular}




\begin{tabular}{cccccccc}
\hline \multicolumn{8}{c}{ Table No. 05: Changes of Stock Prices Regressed on Changes of Interest Rate (Eq-3) } \\
\hline Method & Model & Coefficient & $\begin{array}{c}\mathrm{t}- \\
\text { Value }\end{array}$ & p-Value & $\mathrm{R}^{2}$ & m-Value & m-Prob. \\
\hline \hline $\begin{array}{c}\text { One-way } \\
\begin{array}{c}\text { Random } \\
\text { Effect }\end{array}\end{array}$ & Constant & 1.10 & 4.81 & 0.0001 & & & \\
\hline $\begin{array}{c}\text { Two-way } \\
\text { Random } \\
\text { Effect }\end{array}$ & Constant & 1.10 & 3.78 & 0.0002 & & 0.003 & 0.407 \\
\hline \hline
\end{tabular}

\begin{tabular}{|c|c|c|c|c|c|}
\hline \multicolumn{6}{|c|}{ Table No. 06: Country wise Stock Prices Regressed on Interest Rate (Eq-2) } \\
\hline Country & Model & OLS & $\mathrm{t}-$ Value & p-Value & $\mathrm{R}^{2}$ \\
\hline \multirow{2}{*}{ Australia* } & Constant & 96.81 & 46.401 & 0.0001 & \multirow{2}{*}{0.54} \\
\hline & Interest Rate & -3.95 & -14.54 & 0.0001 & \\
\hline \multirow{2}{*}{ Bangladesh* } & Constant & 244.07 & 12.19 & 0.0001 & \multirow{2}{*}{0.20} \\
\hline & Interest Rate & -14.38 & -6.71 & 0.0001 & \\
\hline \multirow{2}{*}{ Canada* } & Constant & 76.17 & 32.64 & 0.0001 & \multirow{2}{*}{0.37} \\
\hline & Interest Rate & -4.78 & -10.23 & 0.0001 & \\
\hline \multirow{2}{*}{ Chile* } & Constant & 112..58 & 26.93 & 0.0001 & \multirow{2}{*}{0.31} \\
\hline & Interest Rate & -1.97 & -8.97 & 0.0001 & \\
\hline \multirow{2}{*}{ Colombia* } & Constant & 174.30 & 19.53 & 0.0001 & \multirow{2}{*}{0.39} \\
\hline & Interest Rate & -3.48 & -10.84 & 0.0001 & \\
\hline \multirow{2}{*}{ Germany* } & Constant & 78.26 & 22.31 & 0.0001 & \multirow{2}{*}{0.28} \\
\hline & Interest Rate & -6.16 & -8.43 & 0.0001 & \\
\hline \multirow{2}{*}{ Italy* } & Constant & 92.92 & 51.26 & 0.0001 & \multirow{2}{*}{0.81} \\
\hline & Interest Rate & -9.15 & -28.04 & 0.0001 & \\
\hline \multirow{2}{*}{ Jamaica* } & Constant & 102.29 & 15.85 & 0.0001 & \multirow{2}{*}{0.23} \\
\hline & Interest Rate & -2.20 & -7.38 & 0.0001 & \\
\hline \multirow{2}{*}{ Japan* } & Constant & 87.86 & 34.55 & 0.0001 & \multirow{2}{*}{0.26} \\
\hline & Interest Rate & 10.45 & 7.99 & 0.0001 & \\
\hline \multirow{2}{*}{ Malaysia } & Constant & 74.41 & 11.51 & 0.0001 & \multirow{2}{*}{0.02} \\
\hline & Interest Rate & 2.02 & 1.84 & 0.0670 & \\
\hline \multirow{2}{*}{ Mexico* } & Constant & 75.69 & 23.70 & 0.0001 & \multirow{2}{*}{0.39} \\
\hline & Interest Rate & -1.32 & -10.85 & 0.0001 & \\
\hline \multirow{2}{*}{ Philippine } & Constant & 96.04 & 14.75 & 0.0001 & \multirow{2}{*}{0.004} \\
\hline & Interest Rate & -0.49 & -0.90 & 0.3670 & \\
\hline \multirow{2}{*}{ S. Africa* } & Constant & 142.63 & 17.99 & 0.0001 & \multirow{2}{*}{0.33} \\
\hline & Interest Rate & -5.32 & -9.44 & 0.0001 & \\
\hline \multirow{2}{*}{ Spain* } & Constant & 98.14 & 49.86 & 0.0001 & \multirow{2}{*}{0.81} \\
\hline & Interest Rate & -7.50 & -27.50 & 0.0001 & \\
\hline \multirow{2}{*}{ Venezuela* } & Constant & 95.36 & 12.63 & 0.0001 & 17 \\
\hline & Interest Rate & -1.51 & -5.99 & 0.0001 & 0.17 \\
\hline
\end{tabular}

* Alternative is acceptable at $95 \%$ confidence level. 


\begin{tabular}{|c|c|c|c|c|c|}
\hline \multicolumn{6}{|c|}{$\begin{array}{c}\text { Table No. 07: Country wise Changes of Stock Prices Regressed on Changes of } \\
\text { Interest Rate (Eq-3) }\end{array}$} \\
\hline Country & Model & OLS & t-Value & p-Value & $\mathrm{R}^{2}$ \\
\hline \multirow{2}{*}{ Australia } & Constant & 0.57 & 1.94 & 0.054 & \multirow{2}{*}{0.005} \\
\hline & Interest Rate & 0.07 & 0.91 & 0.363 & \\
\hline \multirow{2}{*}{ Bangladesh* } & Constant & 0.53 & 0.68 & 0.497 & \multirow{2}{*}{0.022} \\
\hline & Interest Rate & -0.85 & -2.00 & 0.047 & \\
\hline \multirow{2}{*}{ Canada } & Constant & 0.49 & 1.51 & 0.132 & \multirow{2}{*}{0.008} \\
\hline & Interest Rate & -0.03 & -1.18 & 0.238 & \\
\hline \multirow{2}{*}{ Chile } & Constant & 1.64 & 3.74 & 0.0002 & \multirow{2}{*}{0.021} \\
\hline & Interest Rate & -0.02 & -1.94 & 0.054 & \\
\hline \multirow{2}{*}{ Colombia* } & Constant & 2.00 & 3.01 & 0.003 & \multirow{2}{*}{0.025} \\
\hline & Interest Rate & -0.27 & -2.16 & 0.032 & \\
\hline \multirow{2}{*}{ Germany } & Constant & 0.48 & 1.10 & 0.275 & \multirow{2}{*}{0.002} \\
\hline & Interest Rate & 0.07 & 0.60 & 0.546 & \\
\hline \multirow{2}{*}{ Italy* } & Constant & 0.32 & 0.73 & 0.465 & \multirow{2}{*}{0.023} \\
\hline & Interest Rate & -0.27 & -2.07 & 0.040 & \\
\hline \multirow{2}{*}{ Jamaica } & Constant & 2.27 & 3.22 & 0.002 & \multirow{2}{*}{0.021} \\
\hline & Interest Rate & -0.21 & -1.94 & 0.054 & \\
\hline \multirow{2}{*}{ Japan* } & Constant & -0.34 & -0.94 & 0.350 & \multirow{2}{*}{0.024} \\
\hline & Interest Rate & -0.03 & -2.10 & 0.037 & \\
\hline \multirow{2}{*}{ Malaysia* } & Constant & 0.71 & 1.43 & 0.156 & \multirow{2}{*}{0.032} \\
\hline & Interest Rate & -0.24 & -2.44 & 0.016 & \\
\hline \multirow{2}{*}{ Mexico } & Constant & 2.47 & 3.43 & 0.001 & \multirow{2}{*}{0.003} \\
\hline & Interest Rate & -0.05 & -0.77 & 0.441 & \\
\hline \multirow{2}{*}{ Philippine } & Constant & 0.74 & 0.64 & 0.525 & \multirow{2}{*}{0.013} \\
\hline & Interest Rate & 0.14 & 1.51 & 0.133 & \\
\hline \multirow{2}{*}{ S. Africa* } & Constant & 0.90 & 2.53 & 0.012 & \multirow{2}{*}{0.060} \\
\hline & Interest Rate & -0.25 & -3.36 & 0.001 & \\
\hline \multirow{2}{*}{ Spain } & Constant & 0.62 & 1.38 & 0.169 & \multirow{2}{*}{0.005} \\
\hline & Interest Rate & -0.08 & -0.90 & 0.369 & \\
\hline \multirow{2}{*}{ Venezuela } & Constant & 2.61 & 2.19 & 0.030 & ( \\
\hline & Interest Rate & -0.10 & -1.28 & 0.203 & 0.009 \\
\hline
\end{tabular}

* Alternative is acceptable at $95 \%$ confidence level. 